Jurnal Teknologi, 42(B) Jun. 2005: 11-28

(C) Universiti Teknologi Malaysia

\title{
PERFORMANCE OF LOCALLY PRODUCED COLD-FORMED STEEL SECTIONS FOR ROOF TRUSS SYSTEM
}

\author{
MAHMOOD M. T ${ }^{1}$, THONG, C. M. ${ }^{2} \&$ TAN, C. S. ${ }^{3}$
}

\begin{abstract}
Traditionally, timber is usually used for roof truss as a construction material. However, the use of timber is no longer popular recently due to the increase in cost, not environmentalfriendly as more trees need to be cut, prone to termite attack, and lesser capacity compared with steel. Cold-formed steel section has been introduced in this paper for the construction of roof truss system as an alternative to timber truss. This paper describes experimental test results of the proposed cold-formed produced locally with the code of practice as prescribed by BS 5950 Part 5: 1987 for the use in roof truss system. The tests were also performed to meet the requirements that have been outlined by Public Works Department, Malaysia. The experimental results showed good agreement with BS 5950 Part 5. From the study it can be concluded that the proposed locally produced cold-formed steel sections and the connections are suitable to be used in the roof truss system provided that the design values should not be more than the experimental values.
\end{abstract}

Keywords: Cold-formed steel section, roof truss system, section capacities, C-section, hat-section

Abstrak. Secara tradisi kayu biasanya digunakan untuk kekuda bumbung sebagai bahan binaan. Walau bagaimanapun, kegunaan kayu tidak lagi mendapat sambutan kebelakangan ini disebabkan kos yang tinggi, bukan mesra alam sekitar disebabkan banyak pokok perlu ditebang, terdedah kepada serangan anai-anai dan keupayaan yang rendah dibandingkan dengan keluli. Keratan keluli terguling-sejuk telah dicadangkan di dalam kertas ini bagi pembinaan sistem bumbung kekuda sebagai pilihan lain daripada kekuda kayu. Kertas ini membincangkan keputusan uji kaji bagi cadangan keratan keluli terguling-sejuk yang dikeluarkan oleh pengeluar tempatan sebagaimana yang dinyatakan di dalam kod BS5950 Part 5:1987 bagi kegunaan sistem kekuda bumbung. Ujianujian ini juga adalah untuk menepati keperluan-keperluan yang telah digariskan oleh Jabatan Kerja Raya Malaysia. Keputusan-keputusan ujian dari uji kaji menunjukkan keputusan persetujuan yang baik dengan BS 5950 Part 5. Keputusan uji kaji merumuskan bahawa keratan keluli terguling sejuk keluaran tempatan dan sambungannya sesuai digunakan bagi sistem kekuda bumbung.

Kata kunci: Keratan keluli terguling-sejuk, sistem kekuda bumbung, keupayaan keratan, keratan $\mathrm{C}$, keratan topi

\subsection{INTRODUCTION}

The use of light gauge construction material has been recently highlighted by Public Works Department Malaysia, especially in replacing wood for roof truss system in school buildings. Therefore, cold-formed steel section, which has been proven to be

${ }^{1,2 \& 3}$ Steel Technology Centre, Faculty of Civil Engineering, Universiti Teknologi Malaysia, 81310 Skudai, Johor, Malaysia. 
efficient and widely used in developed countries, is a good alternative to traditional timber truss system. Manufacturers have started to develop new industrial-network system to elaborate the process from manufacturing to construction stage while some of them still import existing technology from abroad. The need for roof truss system using cold-formed section have shown tremendous increase in demand in Malaysia due to the policy changes that require the use of cold-formed steel sections for roof truss system by Public Works Department for most of the government projects. In order to fulfil the technical and performance requirements which have been set by the Public Works Department, a collaborative testing project is carried out by Steel Technology Centre, Universiti Teknologi Malaysia, and Tong Yong Private Limited. The Steel Technology Centre provides technical and expert support in implementing the testing, verification, analysis and design of the proposed cold-formed steel section for the roof truss system.

Cold-formed steel is a steel product that is formed by a steel strip or sheet of uniform thickness, in cold state. The cold-formed steel section, which is regarded as steel strip with uniform profile along its length, is usually used in load bearing application [1]. The use of cold-formed steel section can be found in automobile industry, shipbuilding, rail transport, and construction industry. In building construction, the cold-formed steel is utilised in both non-structural and structural members. As non-structural members, the advantages are more on rust resistance and aesthetic purposes. It is used as non-structural member for wall panelling, doorframes, window frames, and services. As structural members, the usage includes roof sheeting, purlins, truss members, beams, columns, and floor decking in steelconcrete composite construction. Figure 1 shows a typical model of roof truss system formed with cold-formed steel section. A pointed screw system using a hand drill is normally used for the installation of the connections.

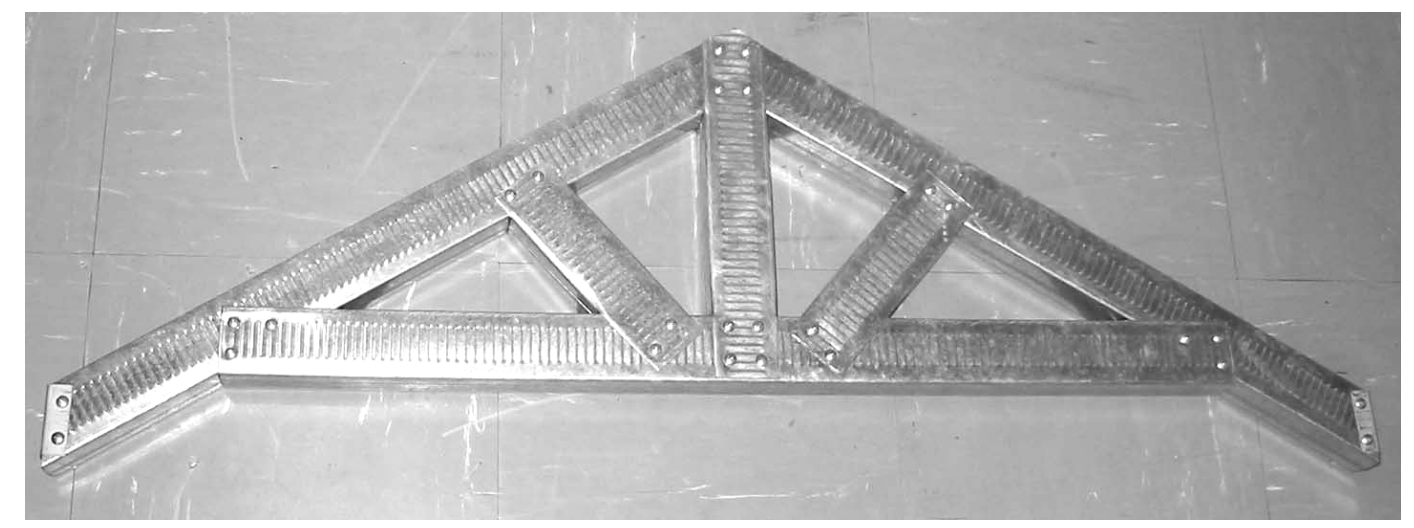

Figure 1 Model of cold-formed steel roof truss system 


\subsection{THE ADVANTAGES OF COLD-FORMED STEEL SECTION}

Generally, cold-formed steel sections have several advantages over hot rolled steel sections and timber trusses. The main advantages are listed as follows [2,3]:

\subsection{No Insect and Fungal Infection}

The problems such as rot and discomposition due to insect and fungal infections are eliminated. Therefore, the material curing and maintenance costs, which are necessary for timber, could be eliminated as well.

\subsection{Consistency and Accuracy of Profile}

The nature of manufacturing process of cold rolling includes the ability of the desired profile to be maintained and repeated for as long as required with minimum tolerances. The consistency and accuracy of the profile can easily be achieved by the use of computer control system. The quality of the section can be efficiently controlled in the factory, and does not depend on environmental factor as in the case of timber.

\subsection{Versatility of Profile Shape}

Almost any desired cross-sectional shapes can be produced by cold rolling, such as T-section, Z-section, dam section, and hat section as shown in Figure 2. The size, length, shape, and thickness can easily be met as the production can automatically be controlled in the production line.

\subsection{Corrosion Resistance by Pre-galvanization or Pre-coating}

The steel material may be pre-galvanized or pre-coated with materials such as zinc hi-ten to enhance its corrosion resistance and attractive surface finish. The coating gives the truss an attractive silver finish and avoids the messy requirement of painting the frames on site.

\subsection{Variety of Connection and Jointing Methods}

All conventional methods of connecting components such as riveting, bolting, welding, screwing, and adhesives material are suitable for cold-formed section. A pointed long screw about $10 \mathrm{~mm}$ long and $5 \mathrm{~mm}$ in diameter was used in this study since it is the fastest and easiest way available in the local market. 


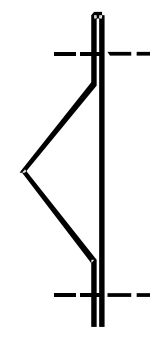

Triangular section

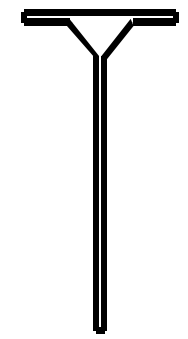

T-section

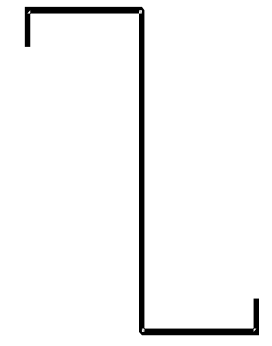

Z-section

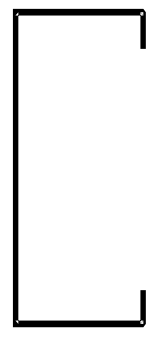

C-section

(a) Cross sections of truss member under consideration

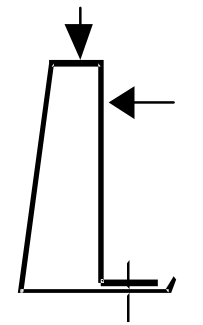

Dam section

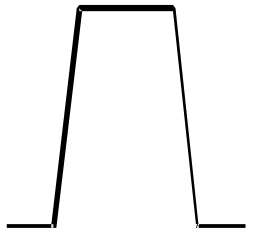

Hat section

(b) Cross sections of purlin under consideration

Figure 2 Various types of cold-formed steel section

\subsection{Speedy in Construction and Easy to Erect}

Generally, steel construction has eliminated the curing time which is inevitable in concrete construction. The use of cold-formed steel section has a better advantage than hot-rolled steel since it can be cut and erected with very light machine and need only one or the most, two workers to install it.

\subsection{Increase in Yield Strength Due to Cold Forming}

The cold forming process introduces local work hardening in the strip being formed in the vicinity of the formed corners. This local work hardening may result in an increment of ultimate yield strength of about $25 \%$ from its expected design strength.

\subsection{Minimum Use of Material}

Since the material used can be very thin in comparison with the lowest thickness limit of hot rolled steel sections, it therefore allows the material usage for a given strength or stiffness requirement to be much less than that of the smallest hot rolled sections. The material thickness, or even the cross-sectional geometries, could be controlled to achieve the structural features with minimum material weight. 


\subsection{Lower in Production Cost and Higher in Profit}

In cold rolled process, the manufacturing costs involve the purchasing of the rolling machine and the steel strip coils. The cost of the machine can be easily recovered in the continuous mass production of the section. The cold formed steel roof truss system, which is in great demand and not enough supply locally can be considered as having a good potential as a construction material. Therefore, the investment required is relatively lower and the return back is sooner than most of other construction materials.

\subsection{DEVELOPMENT OF THE SECTIONS AND CONNECTIONS}

In the production of cold-formed steel sections, the complexity of the formation of the shape would increase the cost margin. To minimise the amount of works in a production line, a section may be designed so that it involves the least number of folding processes and the least amount of folding angle. Therefore, the design of proposed cold-formed $\mathrm{C}$-section and hat section has taken into consideration the difficulty in production line and the cost of production. These new proposed sections need to be established and tested for the roof truss system. Since the typical roof truss system consists of two types of sections which are purlins and truss members, the strength of these sections have to be tested to understand the failure modes and the capacity of the sections. Some of the examples of the proposed $\mathrm{C}$ and hat section are shown in Figure 3. The geometrical configuration of the sections is manufactured by Tong Yong Private Limited with the uniform thickness of $1 \mathrm{~mm}$ for C-section and $0.6 \mathrm{~mm}$ for hat section. The design strength of the material is expected to be in the
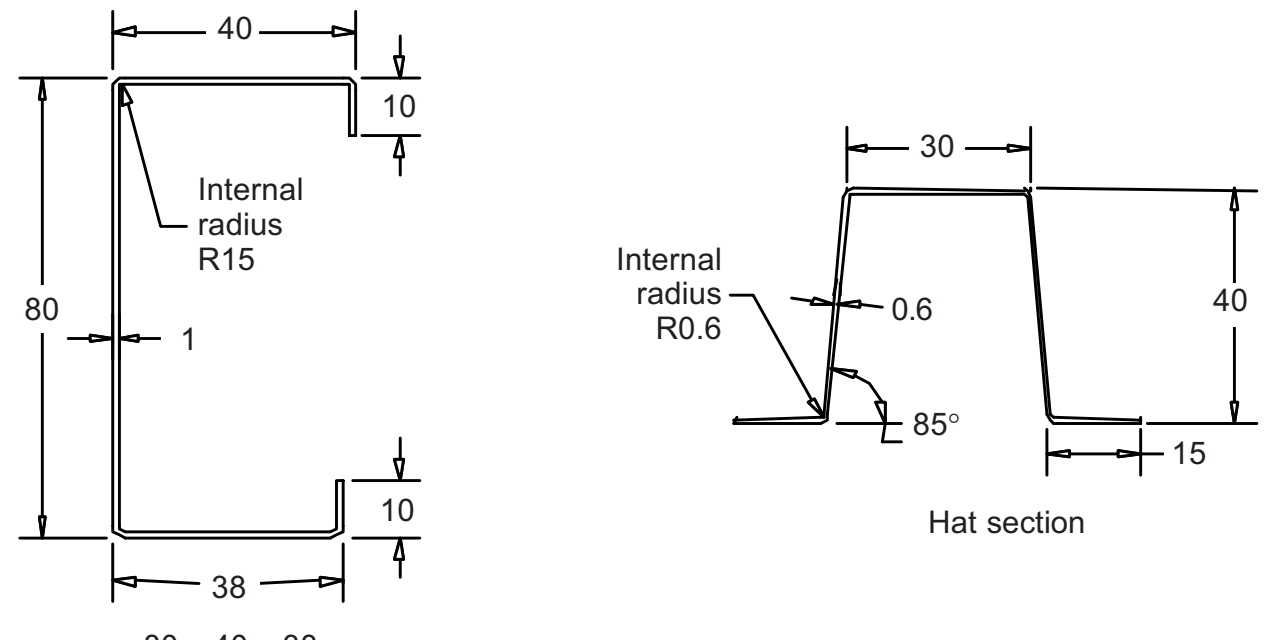

Hat section

$80 \times 40 \times 38$

Figure $380 \times 40 \times 38 \mathrm{C}$-section and hat section 
range of 250 to $300 \mathrm{~N} / \mathrm{mm}^{2}$. The C-section is designed for tension, compression, and bending force in roof truss. For the top chord of the roof truss, the member bent due to the loading of purlin between the nodes in the truss system. Both analytical and experimental approaches were carried out in the study. The method of analysing the strength of the cold-formed was based on BS5950: Part 5:1987 [5]. Experimental work involved testing of the individual capacities of the cold-formed section for tension, compression, bending and dynamic which are discussed later in the paper.

The cold-formed sections were connected together to form members of roof truss system by a group of screws that are formed as connection. The arrangement of screws to form connection can be classified into a group of two and four number of screws. These connections need to be tested for their capacity in shear, tension, and bearing. A cordless drill was used to install the screws to connect the designated section. However, the thickness of the connected section should not be more than 2 $\mathrm{mm}$ as a more powerful drill may be needed to install the screw.

\subsection{ANALYTICAL ANALYSIS}

The capacities of cold-formed C-sections and hat section were estimated using the methods provided in BS5950 Part 5 [5]. Coupon tests were carried out to determine the yield strength of the specimens which have two types of thickness namely 1 and $0.6 \mathrm{~mm}$. The determination of the yield strength is necessary because this value is then applied into the capacities calculation of the tested sections. Three tests were conducted on both $0.6 \mathrm{~mm}$ thick plate (material for hat section) and $1.0 \mathrm{~mm}$ thick plate (material for C-section). The configuration of the test is shown in Figure 4. The failure mode occurred at the middle part of the specimen, as shown in Figure 5. The characteristic yield strength of specimen is achieved by dividing the applied force
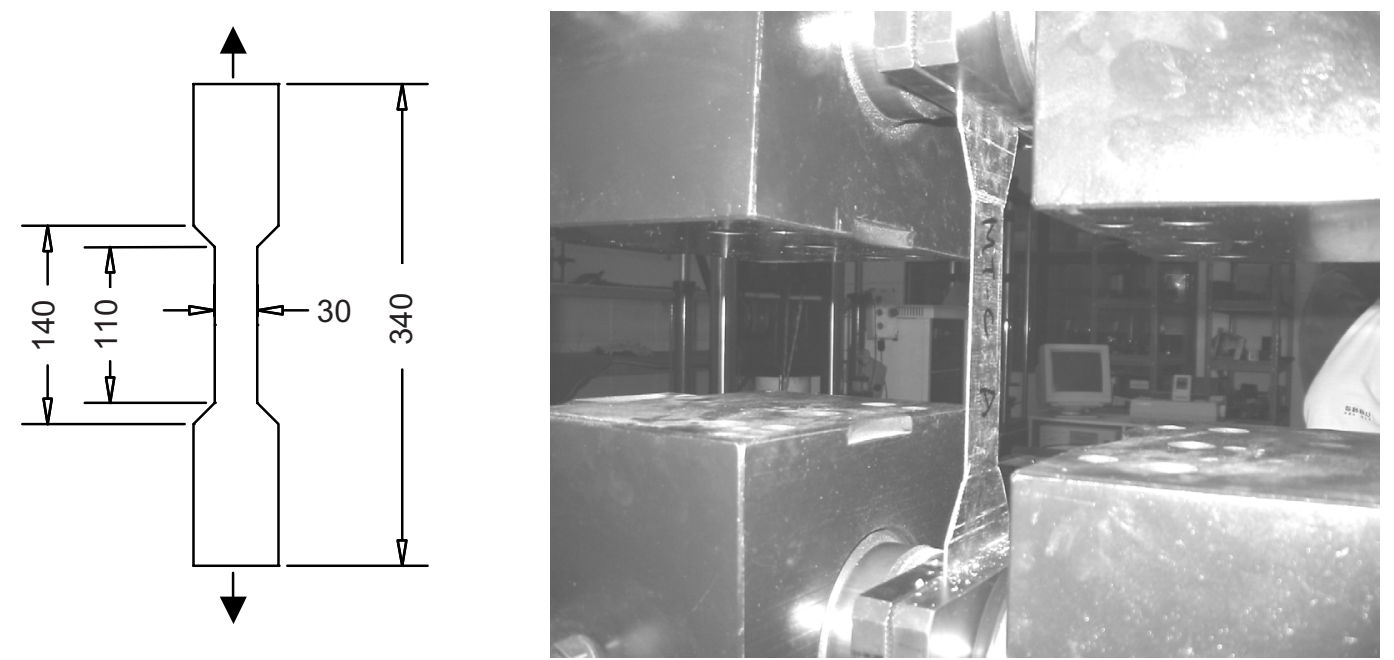

Figure 4 Configuration of the coupon test 


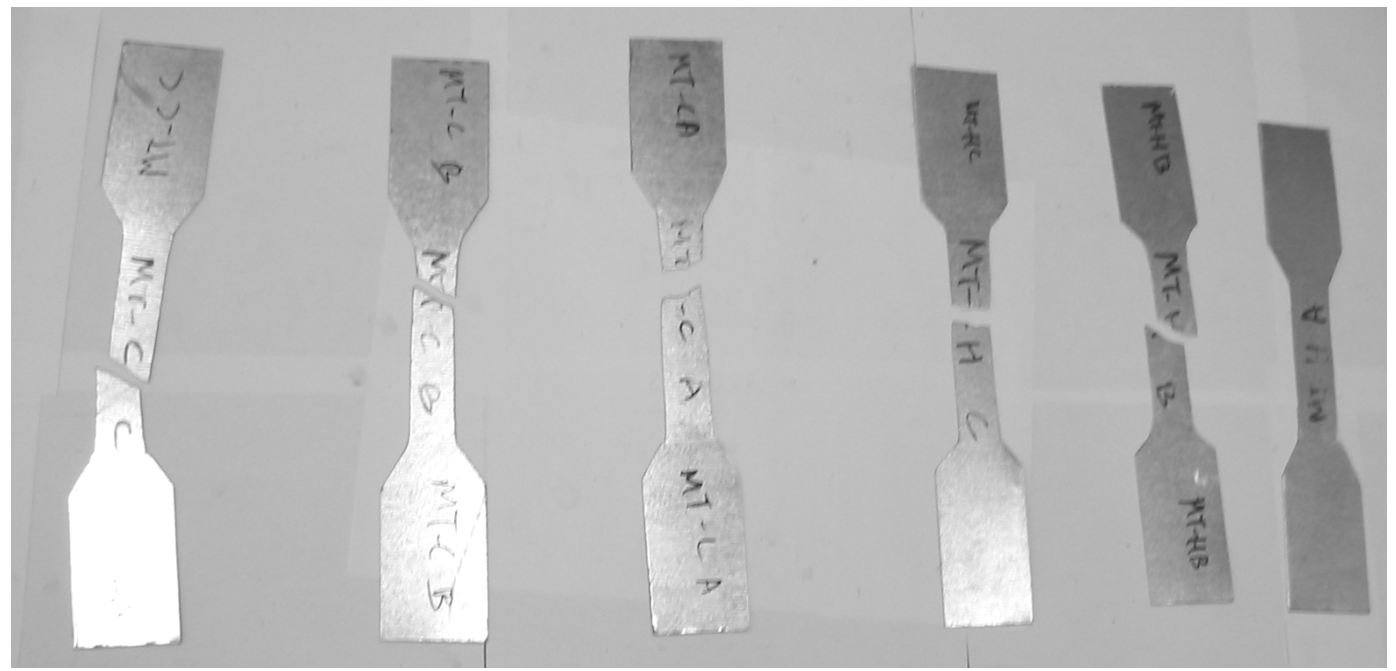

Figure 5 Failure mode of the coupon test

by the cross sectional area of the failure part. The design yield strength was adopted at around 85\% of the characteristic yield strength as in accordance with the code [5]. The applied load in $\mathrm{kN}$ versus stroke in $\mathrm{mm}$ are plotted as shown in Figure 6 (a and b). From calculation, it was determined that the average yield strength for a $0.6 \mathrm{~mm}$ thick plate was $302 \mathrm{~N} / \mathrm{mm}^{2}$ and for a $1.0 \mathrm{~mm}$ plate was $275 \mathrm{~N} / \mathrm{mm}^{2}$. The possible explanation for the difference in the strength is due to the difference in thickness.

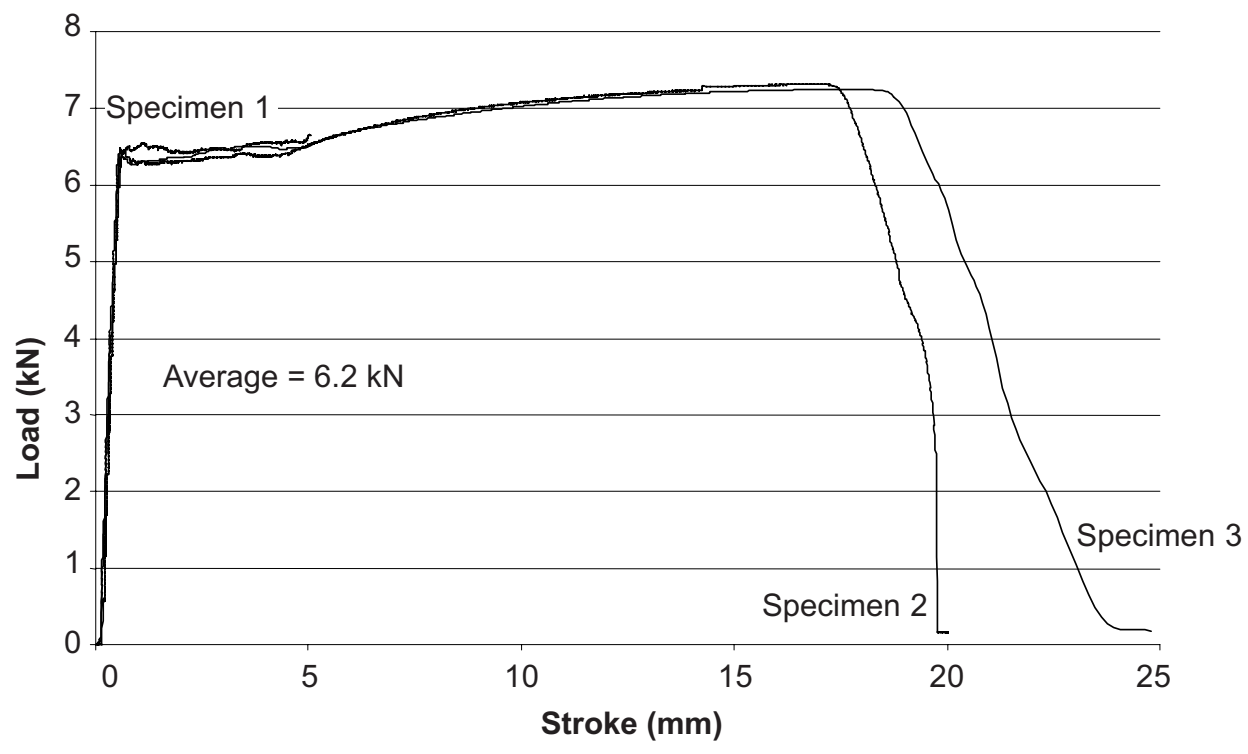

(a) $0.6 \mathrm{~mm}$ plate for hat section 


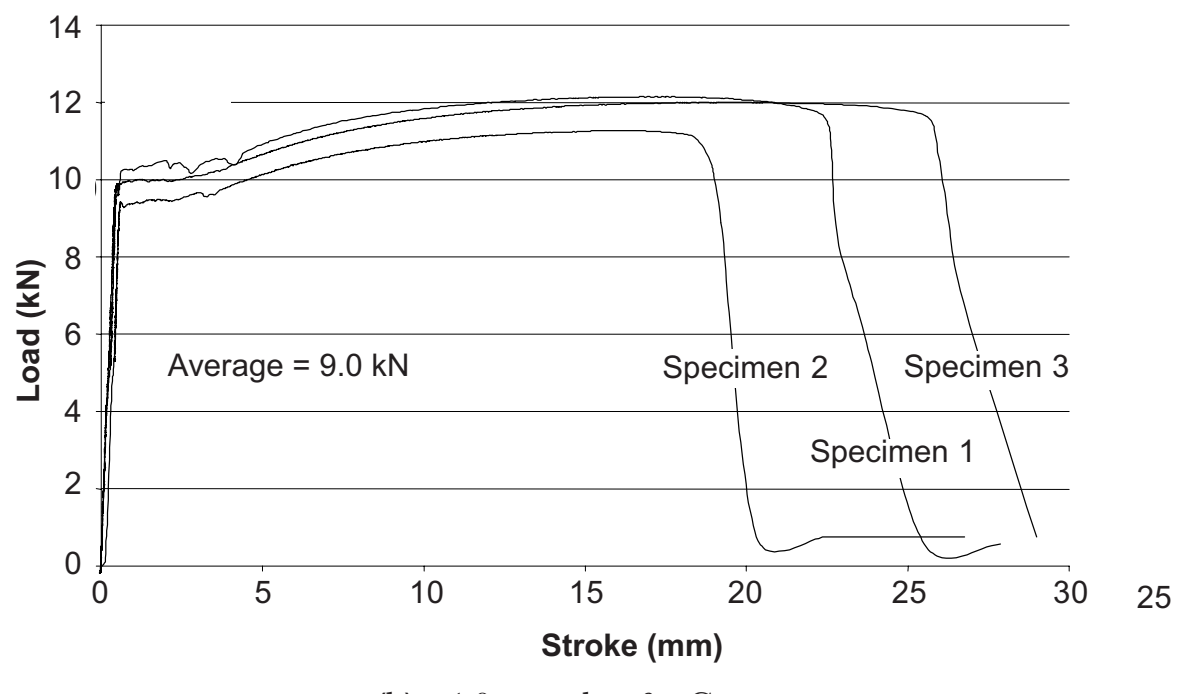

(b) $1.0 \mathrm{~mm}$ plate for C-section

Figure 6 Coupon test results for a $0.6 \mathrm{~mm}$ and $1.0 \mathrm{~mm}$ plate

The yield strength decreased as the thickness increased, which is in line with the expected values as described by BS 4360 [6]. The thinner specimen tends to possess a slightly finer grain structure as a result of faster cooling during the formation of the plate material. As a result, a higher yield strength will be achieved for thinner specimen [7]. The capacities of the specimens are later calculated based on these yield strength values.

Table 1 shows the formula used in the calculation of capacities predicted by BS 5950 Part 5 for the proposed C-sections and hat section. Details of the representation of the terms used in the formula have been described in the code. For dynamic load, the theoretical values are not represented in Table 1 since the requirement of 10000 cycles is the limit suggested by Public Works Department.

\subsection{EXPERIMENTAL ANALYSIS}

The laboratory testing of the $\mathrm{C}$ and Hat sections was carried out in accordance with the code of practice. These test results need to be verified with the formula as described in the code depending on the usage of the section in the roof truss system. The experimental tests were covered on the:

- $\quad$ C-sections, for pure tension test, pure compression test of short strut, pure compression test of $1 \mathrm{~m}$ strut and pure bending test;

- hat sections for pure bending test; and 
PERFORMANCE OF LOCALLY PRODUCED COLD-FORMED STEEL SECTIONS

Table 1 Member capacities of cold-formed $80 \times 40 \times 38$ C-section and hat section

\begin{tabular}{llcc}
\hline Capacities & \multicolumn{1}{c}{ Specimens } & $\begin{array}{c}\text { Formula based } \\
\text { on BS 5950 Part 5 }\end{array}$ & $\begin{array}{c}\text { Capacities } \\
\text { predicted } \\
\text { from BS 5950 } \\
\text { Part 5 }\end{array}$ \\
\hline Pure tension & C-section $80 \times 40 \times 38$ & $P_{t}=A_{t} p_{y}$ & $43.5 \mathrm{kN}$ \\
\hline $\begin{array}{l}\text { Pure compression: } \\
\text { (i) Short strut }\end{array}$ & C-section $80 \times 40 \times 38$ & $P_{c s}=A_{e f f} p_{y}$ & $33.7 \mathrm{kN}$ \\
(ii) 1m slender strut & C-section $80 \times 40 \times 38$ & $P_{c}^{\prime}=\frac{M_{c y} P_{c}}{\left(M_{c y}+P_{c} e_{s}\right)}$ & \\
& Hat-section & $M_{c}=p_{o} Z_{C}$ & $22.84 \mathrm{kN}$ \\
\hline Pure bending & C-section $80 \times 40 \times 38$ & $0.26 \mathrm{kNm}$ \\
\hline Connections: & 1 screw on C-section & Smaller value of: & $0.97 \mathrm{kNm}$ \\
Pull capacity & 2 screws on C-section & $P_{t}=1.1 t_{3} d_{s} p_{y}$ & $0.73 \mathrm{kN}$ \\
& 1 screw on hat-section & $P_{t}=0.65 t_{4} d_{s} p_{y}$ & $0.53 \mathrm{kN}$ \\
& 2 screws on hat-section & & $1.06 \mathrm{kN}$ \\
& 1 screw on $0.6 \mathrm{~mm}$ plate & Smaller value of & $1.90 \mathrm{kN}$ \\
& 2 screws on $0.6 \mathrm{~mm}$ plate & $P_{s}=3.2\left(t_{3}^{3} d\right)^{1 / 2} p_{y}$ & $3.80 \mathrm{kN}$ \\
& 1 screw on $1.0 \mathrm{~mm}$ plate & $P_{s}=2.1 t_{3} d p_{y}$ & $3.40 \mathrm{kN}$ \\
& 2 screws on $1.0 \mathrm{~mm}$ plate & & $6.80 \mathrm{kN}$ \\
& &
\end{tabular}

- $\quad$ connections for pulled off test of 1 and 2 screws connection, for shear test of 2 and 4 screws connection and also dynamic test.

Short strut, which is defined as a $500 \mathrm{~mm}$ long specimen was tested for local buckling capacity whereas for long strut, with the length of $1000 \mathrm{~mm}$ long was tested for the combination of local and overall bucking capacity. Three specimens were tested for each experiment. The lowest experimental value from the specimens was taken as the specimen capacity, and compared with the theoretical values established from the code of practice. This approach is quite conservative, but the requirement is in accordance with Public Works Department. 


\subsection{Pure Tension Test}

The purpose of a pure tension test is to identify the tension capacity of the section. Three specimens of C-section length of $500 \mathrm{~mm}$ and size of $80 \mathrm{~mm}$ long, $40 \mathrm{~mm}$ wide, $38 \mathrm{~mm}$ of vertical height at open channel with $1 \mathrm{~mm}$ thick were tested. To avoid failure due to clamping of the machine, the ends of the specimens were embedded with wood that was fitted on the inner side of the C-section. The configuration of the test is shown in Figure 7. Minimum failure force obtained was $52 \mathrm{kN}$, which was $20 \%$ higher than the estimated tension capacity.
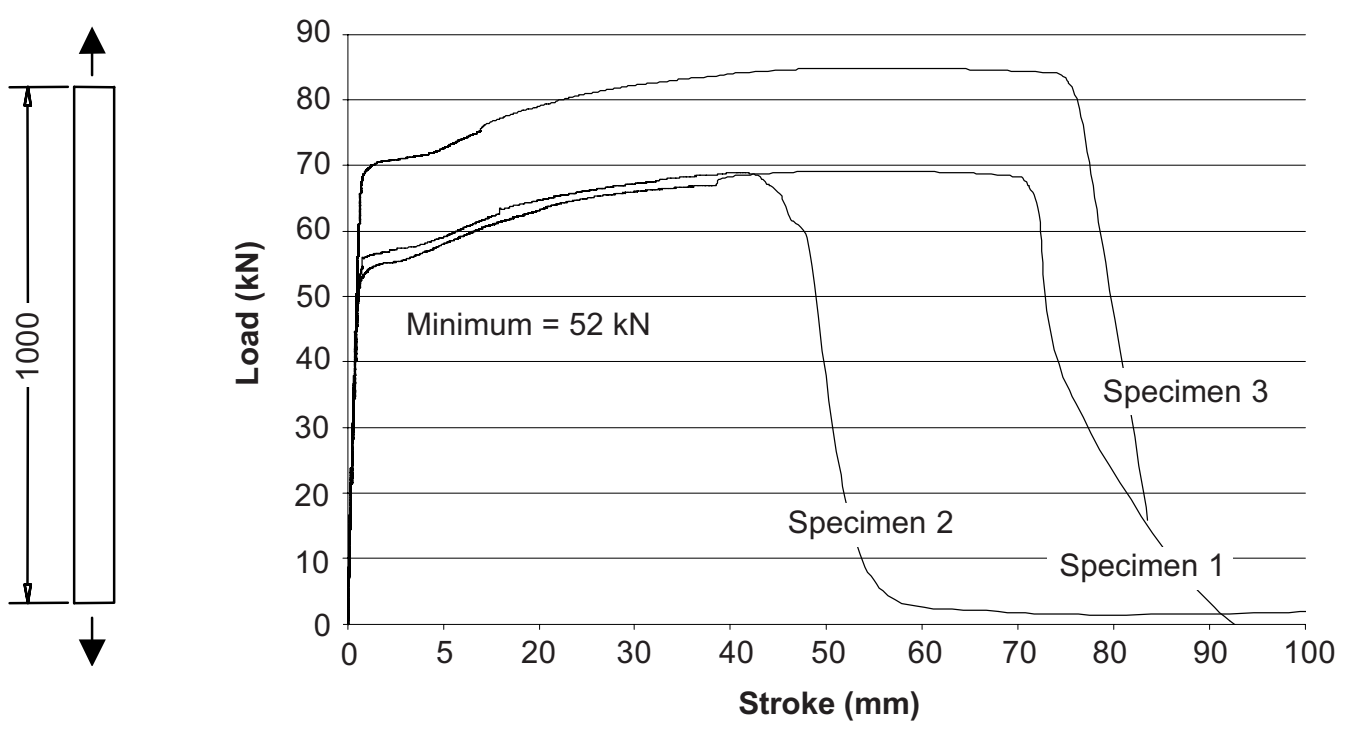

Figure 7 Pure tension test

\subsection{Pure Compression Test on Short Strut}

The short strut specimens represent the capacity of the sections which failed due to local buckling. The code specifies that the length of the specimen of this test may be adopted as three times the width of the longest element of the specimen. Therefore, the test was set as shown in Figure 8. Since the specimens were susceptible to local failure, a solid block of wood was installed at each end of the specimens in order to avoid the end crushing and promote the failure at the middle length. Three specimens were tested in this test. All specimens were fully deformed after test and the minimum failure load was $38 \mathrm{kN}$.

\subsection{Pure Compression Test on 1-meter Long Strut}

The one metre-long strut has been identified as the critical member of the roof truss system designed for school building, which has the actual length of about $1 \mathrm{~m}$. The 

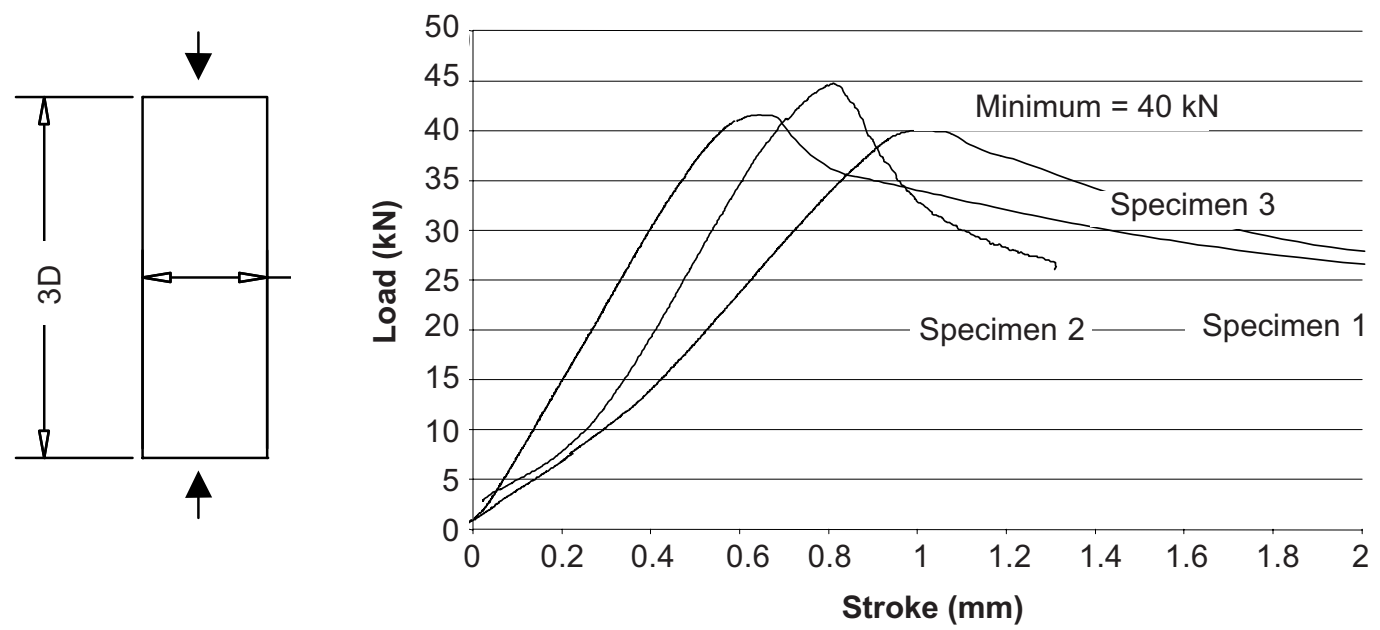

Figure 8 Pure compression test on short strut

method of installation of the specimens to the compression machine was the same as described in 5.2. Figure 9 shows the configuration and results of the test on three specimens. The specimens failed in the expected mode and the average failure load was $26 \mathrm{kN}$.
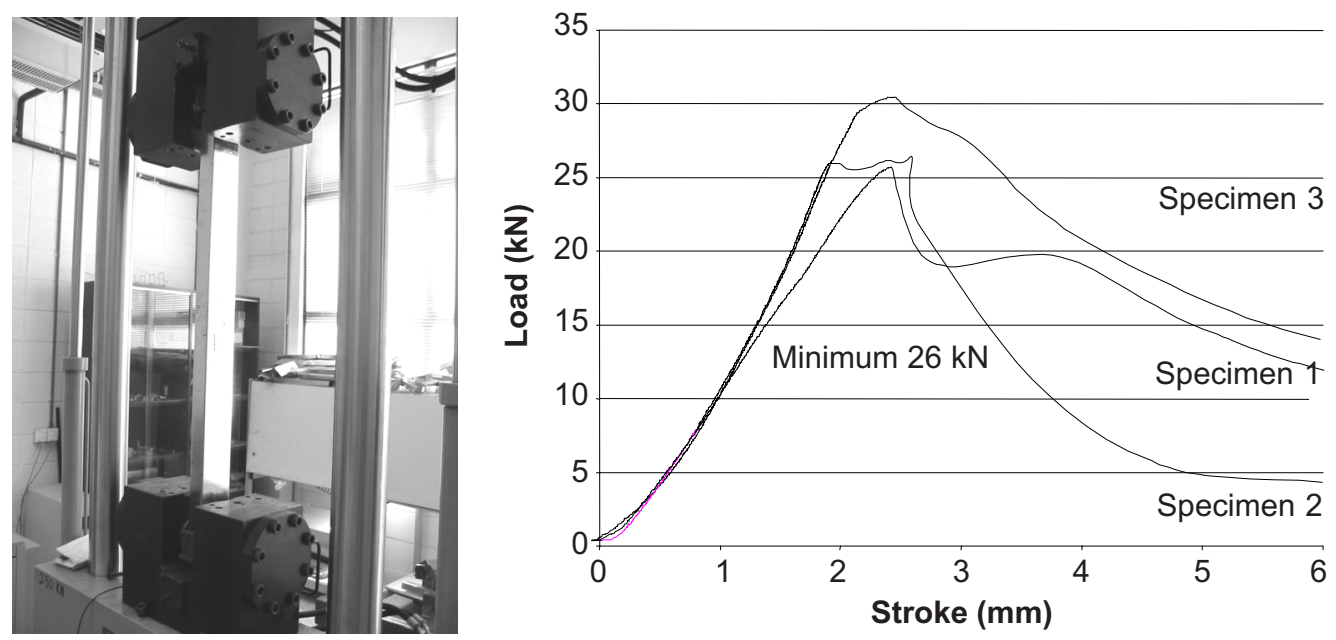

Figure 9 Pure compression test on $1 \mathrm{~m}$ long strut

\subsection{Pure Bending Test}

To identify the pure bending capacity of a specimen, BS 5950 Part 5 limits the length of the member to at least eight times the longest length of the cross-sectional dimension. 
The compression flange should be supported at a distance not greater than 20 times the least radius of gyration of the specimen. Two point loads should be applied to the member in such a way that the formation of bending moment is quite close to the uniform bending moment developed from uniform load. Local buckling may be restrained at the points of applied load to ensure that failure occurs within the central portion of the span. The test was set as shown in Figure 10. Both C-section and hat section, with three specimens of each were tested until failure. The failure loads achieved were $10 \mathrm{kN}$ for C-section and $2.5 \mathrm{kN}$ for hat section.
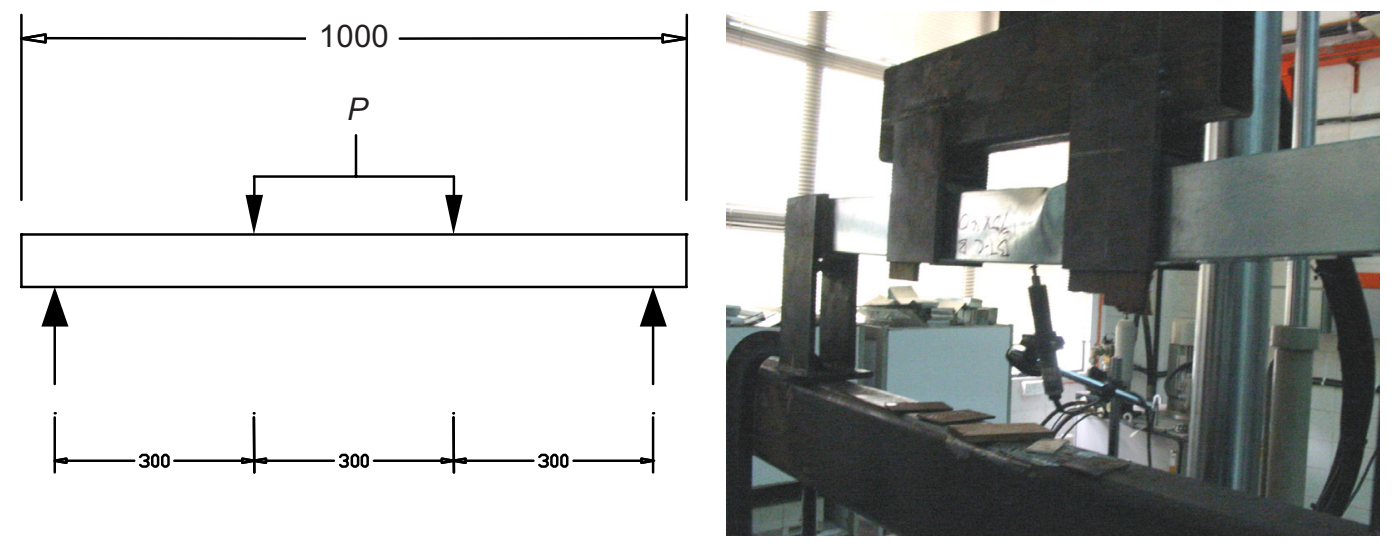

Figure 10 Bending test configuration

\subsection{Testing on Connection}

All C and hat sections are connected together by means of a group of screws to form a connection. These connection need to be tested to cater for any load transfer from the sections of the roof truss. The loads can be in the form of pulling, shearing, and dynamic loads.

\subsubsection{Pull Test on Connection}

The purpose of the test is to identify the resistance of the connection to the pulled-off force, in the direction which is parallel to the screw $[9,10]$. It simulates the real connection especially the connection of purlin to the top chord of roof truss. Four sets of tests with different connected members and different numbers of screws were carried out with each set comprised of three specimens. The failure modes and the measured capacities were in accordance with the expected values. 


\subsubsection{Shear Test on Connection}

This test is also known as a single lap joint shear test. The force is applied in the transverse direction to the screw $[10,11]$. Two-screws and four-screws connections were installed on both $0.6 \mathrm{~mm}$ plate and $1.0 \mathrm{~mm}$ plate. From the tests, it was found that all specimens failed due to bearing of the plate at the hole of the screw, as shown in Figure 11. The results are summarised in Table 2.

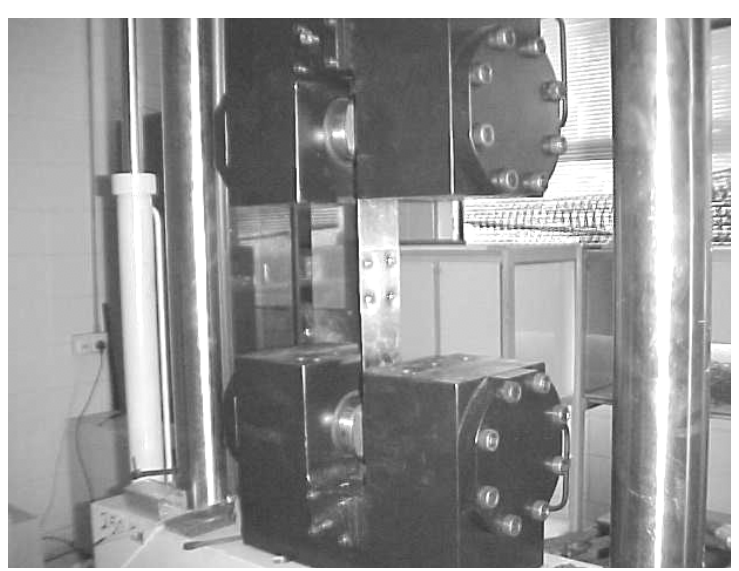

(a) Shear test configuration

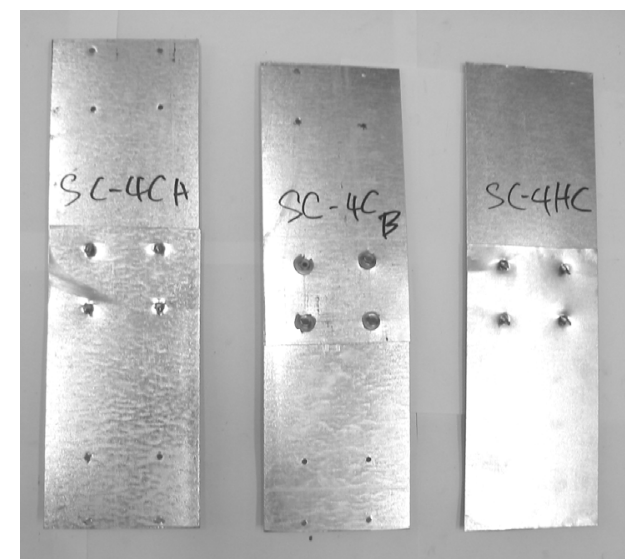

(b) Failure mode of 4 screw connection

Figure 11 Shear test on screw connection

\subsubsection{Dynamic Test on Connection}

The objective of this test is to determine the resistance of the connections to the longterm dynamic load, which may be caused by vibration of fans and fluctuating wind loads. In this test, 10000 cycles of cyclic loading, varying between 0.5 to $5.5 \mathrm{kN}$ was imposed to the connection. After the cyclic loading, it was observed that the screws were slightly tilted to the inner side, as shown in Figure 12. No significant bearing failure was found at the hole of the screw. Therefore, the connection was capable of sustaining the dynamic load at $70 \%$ of its capacity, and it was safe to withstand the loads caused by wind and services in long term.

\subsection{ANALYSIS AND DISCUSSION OF TEST RESULTS}

All experimental tests were carried out successfully and the results were in accordance with the theoretical values derived from the code of practice [5]. The summary of the comparison of results between theoretical values and experimental values is tabulated in Table 2. From the table, it is found that all experimental values are higher than the calculated values, although the yield strength is only taken as $85 \%$ of 


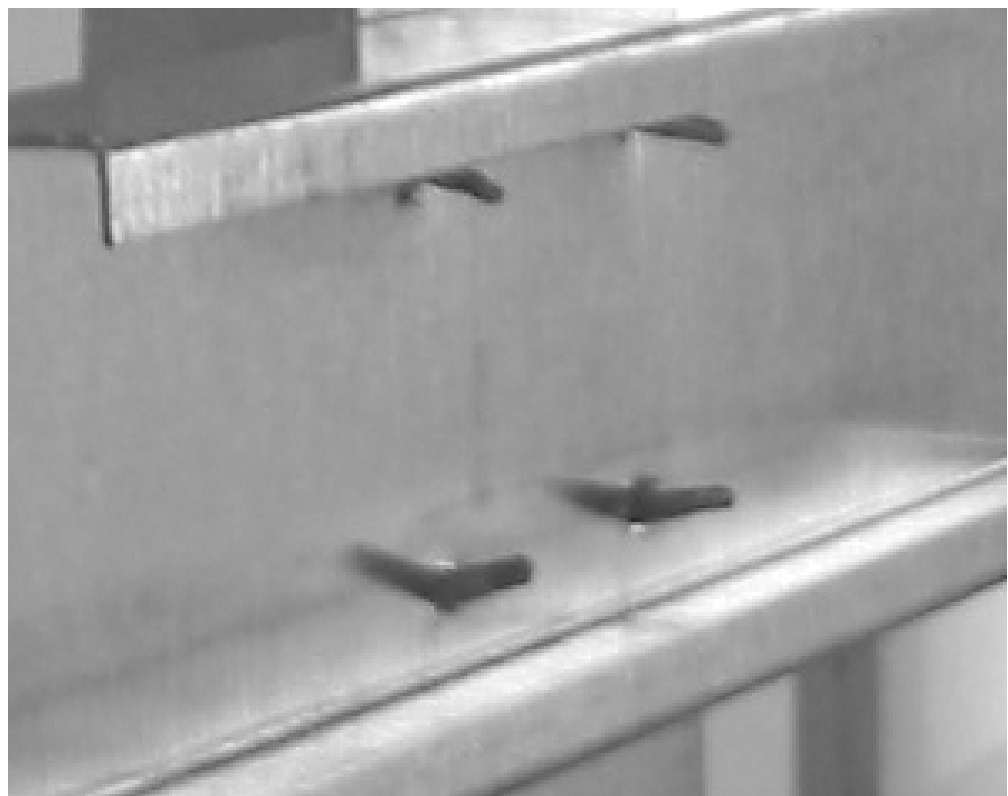

Figure 12 Tilted screws (to the inner side) after dynamic load test

Table 2 Summary of the theoretical capacities predicted from BS 5950 and experimental values results

\begin{tabular}{|c|c|c|c|c|}
\hline Test name & Test detail & $\begin{array}{c}\text { Capacities } \\
\text { predicted } \\
\text { from BS } 5959\end{array}$ & $\begin{array}{c}\text { Experimental } \\
\text { values }\end{array}$ & Comment \\
\hline Pure tension test & C-section $80 \times 40 \times 38$ & $20.66 \mathrm{kN}$ & $26 \mathrm{kN}$ & $\mathrm{Ok}$ \\
\hline \multicolumn{5}{|l|}{ Pure compression: } \\
\hline \multirow{2}{*}{$\begin{array}{l}\text { Short strut } \\
1 \text { meter slender }\end{array}$} & C-section $80 \times 40 \times 38$ & $33.70 \mathrm{kN}$ & $38 \mathrm{kN}$ & $\mathrm{Ok}$ \\
\hline & C-section $80 \times 40 \times 38$ & $22.84 \mathrm{kN}$ & $25 \mathrm{kN}$ & $\mathrm{Ok}$ \\
\hline \multirow[t]{2}{*}{ Pure bending test } & Hat section & $0.26 \mathrm{kNm}$ & $0.38 \mathrm{kNm}$ & $\mathrm{Ok}$ \\
\hline & C-section $80 \times 40 \times 38$ & $0.97 \mathrm{kNm}$ & $1.50 \mathrm{kNm}$ & $\mathrm{Ok}$ \\
\hline \multirow[t]{3}{*}{ Pulling test } & 1 screw on C-section & $0.73 \mathrm{kN}$ & $1.50 \mathrm{kN}$ & $\mathrm{Ok}$ \\
\hline & 2 screws on C-section & $1.46 \mathrm{kN}$ & $3.20 \mathrm{kN}$ & $\mathrm{Ok}$ \\
\hline & 1 screw on Hat-section & $0.53 \mathrm{kN}$ & $1.00 \mathrm{kN}$ & $\mathrm{Ok}$ \\
\hline \multirow[t]{5}{*}{ Shear test } & 2 screws on Hat-section & $1.06 \mathrm{kN}$ & $2.20 \mathrm{kN}$ & $\mathrm{Ok}$ \\
\hline & 2 screws on $0.6 \mathrm{~mm}$ plate & $1.90 \mathrm{kN}$ & $3.00 \mathrm{kN}$ & $\mathrm{Ok}$ \\
\hline & 4 screws on $0.6 \mathrm{~mm}$ plate & $3.80 \mathrm{kN}$ & $7.00 \mathrm{kN}$ & $\mathrm{Ok}$ \\
\hline & 2 screws on $1.0 \mathrm{~mm}$ plate & $3.40 \mathrm{kN}$ & $7.50 \mathrm{kN}$ & $\mathrm{Ok}$ \\
\hline & 4 screws on $1.0 \mathrm{~mm}$ plate & $6.80 \mathrm{kN}$ & $12.50 \mathrm{kN}$ & $\mathrm{Ok}$ \\
\hline
\end{tabular}


its characteristic value. In pure tension test, the experimental result showed good agreement with the theoretical values. The experimental value was $25.8 \%$ higher than the theoretical value, which is good and acceptable. Similarly in pure compression test, the comparison between experimental and theoretical values showed good agreement for both short and long struts. As expected, the test result for short strut is higher than the long strut. This is possible as the long strut deformed earlier due to the combination of local and overall buckling effect, due to longer compression length than short strut. The tested specimens deformed at the mid-length at loads lower than the capacity of compression of the short strut.

Tests on connections showed that the experimental values are higher by almost double the theoretical values. This is possible as the connection deformed first before failure due to bearing. The deformed plate starts to form a wider contact area to the thread of the screw which resulted in reducing the stress and enhancing the shear capacity of the connection. None of the failure mode due to shear occurred at the thread of the screw. This is because the shear strength of the screw is very high, about $1000 \mathrm{~N} / \mathrm{mm}^{2}$, according to the manufacturer. However, the test on the screw has not been carried out in this study due to time and financial constraints. The thicknesses of 0.6 and $1.00 \mathrm{~mm}$ had influenced the shear capacity of the specimens. The shear capacity increased close to linear behaviour as the thickness of the specimens increased. This behaviour is expected as the failure mode was more influenced by the bearing rather than the shearing of the screws.

The test on dynamic was also carried out and the results showed good response measurement. The requirement of Public Works Department is that the connection should not fail due to cyclic load induced by the rotation of ceiling fan. The cycles of loading needed are 10000 cycles and this has been achieved and proven in the test results.

\subsection{APPLICATION OF EXPERIMENTAL TESTS RESULTS TO THE ROOF TRUSS SYSTEM}

The tests results above showed good agreement with the theoretical values. However, the results need to be applied to the design requirements of the roof truss system. As mentioned earlier, the main application of the tested specimens is to apply to the actual design of roof truss system of a school building. Therefore, results of the actual analysis and design of roof truss system of school building need to be adopted and compared with the above experimental results. Figure 13 shows a typical roof truss system for a school building. Full understanding of the application of the proposed section can only be done by full-scale testing of the roof truss system. However, the system has been successfully implemented in the market as roof truss system where the design is based on the strength of the individual sections. Full-scale testing of the truss using different types of cold-formed steel section has been published elsewhere[12]. 


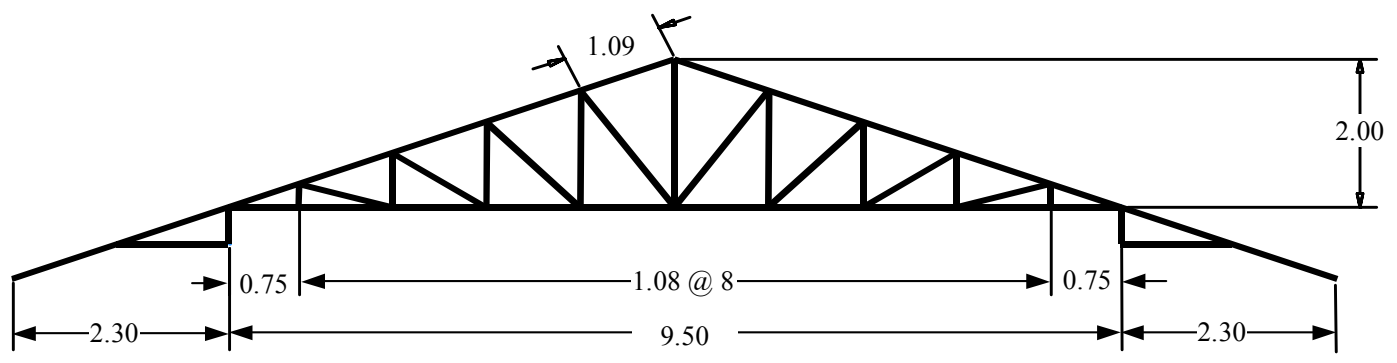

Figure 13 A conventional roof truss system for school building

\subsection{CONCLUSIONS}

The experimental testing of the proposed cold-formed steel C-section and hat section has been carried out successfully and the results showed good agreement with the theoretical values. From the study, further conclusions can be drawn as follows:

(1) The experimental tests results are only valid for the failure mode and capacities of the specimens specifically mentioned above. The results should not be generalised for all shapes of cold-form steel sections.

(2) The experimental results showed that the actual capacities of the specimens that represent the member of roof truss can be predicted and validated. Therefore, it can be concluded that the capacities of the tested specimens can be used in the actual design of the member for roof truss system.

(3) No modification is needed in the application of the specimens to the roof truss system. The proposed C-section and hat section of locally produced cold-formed steel section can be safely used in the roof truss system provided that the design strength should not be greater than the capacity strength of the sections.

Although in this study the test results showed good agreement with the theoretical values, further testing need to be done to understand the global behaviour of the whole structure. It is suggested that a full-scale testing of the proposed roof truss system to be carried out by assembling the proposed sections and connections together, in order to gain further understanding on the failure modes and capacities of the whole system.

\section{REFERENCES}

[1] Rhodes, J. 1991. Design of Cold Formed Steel Members. London: Elsevier Science Publisher.

[2] Rogan, A. L., and R. M. Lawson. 1998. Building Design Using Cold Formed Steel Sections-Value E Benefit Assessment of Light Steel Framing in Housing. UK: Steel Construction Institute.

[3] Trebilcock, P. J. 1993. Building Design Using Cold-formed Steel Sections: An Architect's Guide. UK: Steel Construction Institute. 
[4] Grubb, P. J., and R. M. Lawson. 1997. Building Design Using Cold-formed Steel Sections: Construction Detailing and Practice. UK: Steel Construction Institute.

[5] British Standard Institute 1987. British Standard: Structural Use of Steelwork in Building, Part 5. Code of Practice for Design of Cold Formed Sections. London: BS5950 Part 5: 1987

[6] British Standards Institute. 1986. BS 4360. Specification for Weldable Structural Steels.

[7] Nethercot, D. A. 1991. Limit States Design of Structural Steelwork, Second Edition. 2-6 Boundary Row, London SE1 8HN: Chapman \& Hall.

[8] European Convention for Constructional Steelwork. 1983. The Design and Testing of Connections in Steel Sheeting and Sections. London: ECCS-TC7. Publication No. 21.

[9] European Convention for Constructional Steelwork. 1983. Mechanical Fasteners for use in Steel Sheeting and Sections. London: ECCS-TC7. Publication No. 35.

[10] Olli K., J. Kesti, and P. Makelainen. 2001. The Behaviour of a New Type of Connection System for Lightweight Steel Structures Applied to Roof Trusses. Techno-press: Steel and Composite Structures. 1(1): 17-32.

[11] Thong, C. M. 2003. Development of New Cold-formed Steel Sections for Roof Truss System. Master Thesis. Universiti Teknologi Malaysia.

[12] Tahir, M. Md., S. Saad, A. L. Saleh, and C. K. Tan. 2003. Full-Scale Testing for Roof Truss System Using Cold-Formed Steel Sections. Easec Asia Structural Engineering Conference EASEC09 Bali. Indonesion. 16-18 Dec. 